\title{
Effect of Inoculum Density of Stromatinia cepivora on the Ability of Sclerotial Mycoparasites to Suppress White Rot in Garlic
}

\author{
Ibrahim Elshahawy ${ }^{1,}$, , Nehal Saied ${ }^{1}$, Farid Abd EI Kareem ${ }^{1}$, Ahmed Morsy ${ }^{1}$, Mahmoud Hozien ${ }^{2}$ \\ ${ }^{1}$ Plant Pathology Department, National Research Centre, Giza, Egypt \\ ${ }^{2}$ Agronomy Department, National Research Centre, Giza, Egypt
}

Email address:

ibrahim_nre@yahoo.com (I. Elshahawy)

${ }^{*}$ Corresponding author

To cite this article:

Ibrahim Elshahawy, Nehal Saied, Farid Abd El Kareem, Ahmed Morsy, Mahmoud Hozien. Effect of Inoculum Density of Stromatinia cepivora on the Ability of Sclerotial Mycoparasites to Suppress White Rot in Garlic. Journal of Diseases and Medicinal Plants.

Vol. 4, No. 2, 2018, pp. 48-58. doi: 10.11648/j.jdmp.20180402.12

Received: April 26, 2018; Accepted: May 15, 2018; Published: May 29, 2018

\begin{abstract}
White rot, an garlic disease caused by the soil-borne fungus $S$. cepivora, is a serious problem of garlic productions in Egypt. This study examines the potential of controlling the disease biologically by using three sclerotial mycoparasites i.e., Chaetomium globosum (Chg6), Clonostachys rosea (Cr12) and Penicillium oxalicum (Po9) employed either alone or in combinations. In in vitro assays, these sclerotial mycoparasites showed high antagonistic effect against $S$. cepivora isolate (Sc8). In greenhouse experiments, the chemical treatment of tebuconazole was the most effective, with the lowest incidence of white rot in garlic compared to the control. Sclerotial mycoparasites either alone or in combinations significantly reduced the incidence of white rot in garlic. In general, dual and triple combinations of the sclerotial mycoparasites were more effective than these isolates used individually. In field experiments, under low (40 sclerotia $/ \mathrm{kg}$ of soil) and high ( $600 \mathrm{sclerotia} / \mathrm{kg}$ of soil) inoculum levels, the standard fungicide programme gave statistically significant white rot control, decreasing disease incidence by $67.7 \& 32.4 \%$ in $2016 / 2017$ season and $72.6 \& 31.1 \%$ in 2017/2018 season, respectively. Under low inoculum levels, significant control, equal to the fungicide treatment, was achieved with the triple combination of three sclerotial mycoparasites. However, no sclerotial mycoparasites employed alone give significant control of garlic white rot under high inoculum levels. The triple combination of three sclerotial mycoparasites decreasing disease incidence by $70.8 \& 25.9 \%$ in $2016 / 2017$ season and $73.7 \& 27.6 \%$ in 2017/2018 season, under low and high inoculum levels, respectively. The activities of defense enzymes, i.e. peroxidase, polyphenoloxidase and chitinase due to application of sclerotial mycoparasites were enhanced in garlic plants either grown under low or high inoculum levels. Reduction of white rot disease incidence was accompanied by increasing growth parameters and bulbs yield of garlic plants grown under field conditions. These results concluded that the performance of sclerotial mycoparasites may be influenced as much by the absolute disease pressure. At the low disease pressure site, the low level of S. cepivora inoculum enabled sclerotial mycoparasites to bring about disease control.
\end{abstract}

Keywords: Garlic, White Rot Disease, Inoculum Density, Sclerotial Mycoparasites

\section{Introduction}

Garlic (Allium sativum L.) is a monocotyledonous plant and belongs to the family Alliaceae. It is the second most widely cultivated vegetable next to onion and widely produced for its medicinal and nutritional properties. The annual world garlic production is about 22.2 million tons [1]. In 2016, Egypt produced approximately247,000 metric tons garlic from 10,473 hectares [2]. Unfortunately, in Egypt and in several other countries, garlic is liable to infection by several soil-borne fungi which affected on both quantity and quality of the cloves after harvest [3]. White rot disease caused by the soil-borne pathogen Stromatinia cepivora (Berk). Whetzel, is one of the most important and destructive diseases of garlic and is prevalent worldwide [4, 5]. Stromatinia cepivora produces no functional spores. Instead, 
it propagates by the production of round, poppy-seed-sized (0.3-0.6 $\mathrm{mm}$ in diameter), and black sclerotia on the roots of decayed host plants. Sclerotia of $S$. cepivora spread via mass movement of soil or water and especially on infested plant parts. Once introduced into an area, S. cepivora is moved gradually from field to field on contaminated equipment or planting materials; slowly, the production of garlic in the entire region is threatened. Furthermore, once a field is infested, it will remain so for at least 40 years and probably longer because sclerotia of the fungus remain dormant indefinitely in the absence of Allium hosts [6]. Garlic culture is perhaps the principal mode of movement because it is propagated vegetatively, and garlic bulbs and cloves are sufficiently large that an infestation by mycelia or a few sclerotia might go unnoticed. Initial infestations of $S$. cepivora in afield usually are limited to patches of less than a few hundred plants when the disease is first noticed. In subsequent Allium crops, inoculum density increases, and disease incidence increases [7]. Soil temperature and seasonal time of planting also are important determinants of final disease incidence [8]. The severity of white rot is related directlyto the number of sclerotia in the soilat planting [7]. An inoculum density of a few sclerotia in a liter of field soil potentially can results in crop failure [7]. Loss estimates are difficult to ascertain because once white rot is identified in a field, growers are forced to grow other nonsusceptible (non-Allium) crops. Hence, infested fields often are abandoned from further garlic production.

No field treatment has yet been developed to completely eradicate the fungus from soil. There are few effective chemicals or other methods to control garlic white rot [9], and host resistance is not sufficient to provide commercially acceptable control [10]. As a result, attempts to manage the disease have focused on reducing the populations of sclerotia in the soil. In previous study, on onion, the fungal isolates Chaetomium globosum (Chg6) Kunze, Clonostachys rosea (Cr12) (Link) Schroers and Penicillium oxalicum (Po9)Currie $\&$ Thom were confirmed as antagonists of Stromatinia cepivora onion isolate $(\mathrm{Sc} 2)$ and parasitized on their sclerotia [11]. We also found that in dual culture with S. cepivora, these isolates produced inhibition zones and colonized pathogen hyphae. When agar was amended with culture filtrates of Ch. Globosum (Chg6), $\mathrm{Cl}$. rosea (Cr12) and $\mathrm{P}$. oxalicum, the growth of $S$. cepivora was distorted or unusual, indicating the production of antibiotics [11]. Therefore, this paper reports the results of tow field trials which compared the standard fungicide programme for garlic white rot withsolid substrate formulations of Ch.globosum (Chg6), Cl. rosea $(\mathrm{Cr} 12)$ and $P$. oxalicum employed alone or in combination applied at sowing under varying disease pressures.

\section{Materials and Methods}

\subsection{Garlic White Rot Pathogen}

One isolate of $S$. cepivora ( $\mathrm{Sc} 8)$ was obtained from the author's collection. This isolate was found to be of high virulence against garlic based on pathogenicity tests conducted in previous studies [5].

\subsection{Sclerotial Mycoparasites}

Three identified sclerotial mycoparasites including Chaetomium globosum (Chg6), Clonostachys rosea (Cr12) and Penicillium oxalicum (Po9) were obtained from Plant Pathology Department, National Research Centre. Isolation and identification of these isolates as sclerotial mycoparasites of $S$. cepivora were confirmed in previous study [11].

\subsection{Testing the Antagonistic Activity Against S. Cepivora (Sc8)}

Each of the Ch. globosum (Chg6), C. rosea $(\mathrm{Cr} 12)$ and $P$. oxalicum (Po9) was tested for antagonism for $S$. cepivora (Sc8) using the dual culture techniques [12]. PDA plates were inoculated on one side with a $5 \mathrm{~mm}$ mycelial disk from a 7 day-old culture of the test fungus. The opposite side was inoculated with a disc of $S$. cepivora $(\mathrm{Sc} 8)$ and the plates were incubated at $18 \pm 2^{\circ} \mathrm{C}$ in the dark. Four replicate plates were inoculated for each test fungus. After 14 days, the following parameters were measured: (i) average growth area $\left(\mathrm{cm}^{2}\right)$ in both dual culture and control and (ii) average number of sclerotia (in $\mathrm{cm}^{2}$ ) in both dual culture and control and (iii) average area of inhibition zone.

\subsection{Parasitism of Sclerotia}

Sclerotia of garlic pathogen S. cepivora $(\mathrm{Sc} 8)$, produced in culture by the method of Crowe et al., [7], were surface sterilized in $1 \%$ sodium hypochlorite for $4 \mathrm{~min}$, rinsed in sterile distilled water for $5 \mathrm{~min}$ and placed around the periphery of 7 -day-old colonies of the test fungi grown on water agar plates. Plates were sealed to prevent desiccations and incubated at $18 \pm 2{ }^{\circ} \mathrm{C}$. After 3 weeks, sclerotia were examined microscopically for evidence of parasitism. Uninfected sclerotia and sclerotia naturally infected with each of Ch.globosum (Chg6), C. rosea (Cr12) and $P$. oxalicum (Po9) were also examined microscopically. A sample from each group of parasitized sclerotia was removed and transferred to fresh PDA to determine their viability.

\subsection{Inhibitor Effect of Cultural Filtrate Against Growth of S. cepivora (Sc8)}

The effect of culture filtrates of sclerotial mycoparasites on radial growth of $S$. cepivora $(\mathrm{Sc} 8$ ) isolates was tested using PDA (potato dextrose agar) plates amended with culture filtrates of the tested sclerotial mycoparasites [11]. Potato dextrose broth (PDB) medium (1 L; pH 6.5-6.8) containing $200 \mathrm{~g}$ potato and $20 \mathrm{~g}$ dextrose was prepared and $100 \mathrm{ml}$ were distributed into $250 \mathrm{ml}$ clean flasks and autoclaved. A 5 $\mathrm{mm}$ mycelial disk from a 7-day-old culture of the test sclerotial mycoparasite was added to each flask. Three replicate flasks were prepared. The flasks were incubated on a rotary shaker at room temperature for 10 days. The cultures were then filtered off under vacuum and the filtrate 
centrifuged at $2500 \mathrm{~g}$ for $20 \mathrm{~min}$. Twenty-five $\mathrm{ml}$ of the supernatant were re-filtered through a sterile 0.22 um Millipore filter directly into $225 \mathrm{ml}$ molten PDA. The amended PDA was poured into Petri dishes and after cooling, the plates were centrally inoculated with a $5 \mathrm{~mm}$ diam. mycelial disc from the edge of a 7-day-old colony of $S$. cepivora (Sc8). Un-amended PDA medium, prepared as above but without the filtered culture supernatant, was used as a control. Five replicate plates with each filtrate were made. The plates were incubated at $18 \pm 2^{\circ} \mathrm{C}$ for 14 days. Qualitative analysis of any changes in growth form of $S$. cepivora ( $\mathrm{Sc} 8)$ was recorded visually: (-) no change, $(+)$ colony compact and dense, hyphae more branched and no sclerotia formed, and $(++)$ no growth. Tebuconazole (commercialized as Folicur ${ }^{\circledR}, 25 \%$ ai. Bayer Group Science, Germany) was used in the above experiments for comparison. The chemical treatment was applied at the recommended rate of $1.0 \mathrm{ml}$ Folicur/ L.

\subsection{Inhibitor Effect of Cultural Filtrate Against Sclerotial Germination}

Sclerotia were collected from S. cepivora (Sc8) cultures (60-day-old) and soaked in test tubes containing the culture filtrate of each of the sclerotial mycoparasites to be tested for $12 \mathrm{~h}$ at room temperature. At end of the soaking period, sclerotia were washed with sterile distilled water and thirty sclerotia from each treatment were transferred individually under aseptic conditions to Petri-dishes containing PDA. Water-soaked sclerotia were used as the control treatment. Four replicates (dishes) were used for each treatment. Petri dishes bearing sclerotia were incubated at $18-20^{\circ} \mathrm{C}$ for 7 days and percentages of germinating sclerotia were determined. Tebuconazole was used at the rate of $1.0 \mathrm{ml}$ Folicur/ $\mathrm{L}$ for comparison.

\subsection{Greenhouse Experiments}

\subsubsection{Preparation of Sclerotial Mycoparasites Inocula}

Ch. globosum (Chg6), C. rosea (Cr12) and P. oxalicum (Po9) used in this study were grown on sterilized $\left(121^{\circ} \mathrm{C}\right.$ for $60 \mathrm{~min}$ ) wheat bran as a carrier preparation [13]. Carboxymethyl cellulose (1\%) was used as an adhesive at the rate of 1:10 (v/w). The $\mathrm{pH}$ was adjusted to neutral by adding $\mathrm{CaCO}_{3}$ at the rate of $15 \mathrm{~g} / \mathrm{kg}$. Mannitol was added as osmoticant at the rate of $8.5 \mathrm{ml}$ of $3 \%$ mannitol for $100 \mathrm{~g}$ formulation. Spore suspension $\left(10^{6}\right.$ spores $\left./ \mathrm{ml}\right)$ of each of $C h$. globosum (Chg6), C. rosea (Cr12) and P. oxalicum (Po9) were incorporated into sterilized wheat bran under aseptic conditions at the rate of $50 \mathrm{ml}$ of suspension per $100 \mathrm{~g}$ and thoroughly mixed with a sterilized spoon. The materials (35\% moisture content) were packed in polythene bags, sealed and stored at room temperature. These formulations used alone or their dual and triple combinations (equal volumes of each) were applied in the greenhouse and field experiments.

\subsubsection{Preparation of Garlic White Rot Pathogen Inocula}

Fungal mass of garlic isolate S. cepivora ( $\mathrm{Sc} 8)$ for soil infestation in greenhouse experiments was obtained by growing the isolate on a sand-barley medium [14]. This medium was prepared by mixing $50 \mathrm{~g}$ barley grains, $50 \mathrm{~g}$ sand and $40 \mathrm{~mL}$ water; then the mixture in glass bottles $(500 \mathrm{~mL}$ capacity) with cotton plugs was sterilized at $121^{\circ} \mathrm{C}$ for 30 min. The autoclaved medium was inoculated with a $5 \mathrm{~mm}$ disk of $S$. cepivora $(\mathrm{Sc} 8)$ and incubated at $18 \pm 2{ }^{\circ} \mathrm{C}$ for 5 weeks.

\subsubsection{Effects of Sclerotial Mycoparasites on Garlic White Rot Disease Development}

The effects of the three sclerotial mycoparasites i.e., Ch. globosum (Chg6), C. rosea (Cr12)and P. oxalicum (Po9)and their combinations (equal volumes of each) were investigated on the development of white rot disease on garlic in soil artificially infested with $S$. cepivora $(\mathrm{Sc} 8)$. The experiment was carried out in pots under greenhouse conditions (the minimum and the maximum temperatures were $5-10^{\circ} \mathrm{C}$ and $20-25^{\circ} \mathrm{C}$, respectively) using susceptible cultivar of garlic as in El-Sheshtawi et al. [15]. The experiments were conducted with a completely randomized design (CRD) with nine treatments (seven of the three selected sclerotial mycoparasites and their combinations of Ch. globosum (Chg6), C. rosea (Cr12) and P. oxalicum (Po9), Chg6 +Cr12, Chg6 +Po9, Cr12 +Po9, Chg6+Cr12+Po9, bioformulated on wheat bran previously described, chemical fungicide and infected control) each with four replicates. Each replicate consisted of a sterilized plastic pot $(30 \mathrm{~cm}$ diameter $)$ containing $5 \mathrm{~kg}$ of autoclaved loamy clay soil pre-infested with $S$. cepivora $(\mathrm{Sc} 8)$ at the rate of $2 \%(\mathrm{w} / \mathrm{w}) 2$ weeks before sowing. The formulated sclerotial mycoparasites were added (at the rate of $1 \% \mathrm{w} / \mathrm{w}$ ) to the infested soil one week before planting. The chemical treatment was applied according to the standard fungicide programme (garlic cloves dipped in $1.0 \mathrm{ml}$ Folicur plus foliar spray). The chemical treatment was applied according to the standard fungicide programme. In this programme garlic cloves were dipped and sprayed (two time intervals 6 weeks in between) with $1 \mathrm{ml} / \mathrm{L}$ Folicur. Before chemical treatment, cloves were superficially disinfected by dipping in sodium hypochlorite solution $(0.25 \%)$ for 2 min and rinsed after surface-sterilization with sterile distilled water. Five surface disinfected garlic cloves (cv. Sides 40) were sown in each pot. Nitrogen fertilizer in form of urea $(46 \% \mathrm{~N})$ was added at the rate of $10 \mathrm{~g} /$ pot 30 days after planting and plants were irrigated when necessary. The percentages of disease incidence were calculated after 100 days after planting as follows: Disease incidence $(\%)=$ $100 \times$ No. of infected plants/No. of total plants [16].

\subsection{Field Experiments}

\subsubsection{Selection of Trials Location}

Field trials were located in El-Deer village, El-Qalubia governorate in which white rot disease was of high commercial interest. In this region, several fields with a wellestablished history of white rot disease were sampled preliminarily for inoculum levels determinations according to the procedure of Utkhede and Rahe [17]. After that, two field 
sites were chosen. One of them was characterized by their low sclerotial density and had an average of 40 sclerotia per 1 kilogram soil. The second was characterized by high sclerotial density and hadan average of 600 sclerotia per 1 kilogram soil.

\subsubsection{Effects of Trichoderma Species on Garlic White Rot Disease Development}

Two field trials were used to estimate the efficiency of the three selected sclerotial mycoparasites and their combinations for controlling white rot disease of garlic plants. The low sclerotial density trial had an average of 40 sclerotia per 1 kilogram soil and the high sclerotial density second trial had 600 sclerotia per 1 kilogram soil. For each trial, the experiments were conducted with a completely randomized design (CRD) with nine treatments (seven of the three selected sclerotial mycoparasites and their combinations of Ch. globosum (Chg6), C. rosea (Cr12) and P. oxalicum (Po9), Chg6 +Cr12, Chg6 +Po9, Cr12 +Po9, Chg6+Cr12 +Po9, bioformulated on wheat bran previously described, chemical fungicide and control) each with four replicates plots. The plot area was $3.0 \times 3.5 \mathrm{~m}\left(10.5 \mathrm{~m}^{2}\right)$ each plot included 6 rows (each $3.0 \mathrm{~m}$ length and $50 \mathrm{~cm}$ width). Each treatment preparation freshly prepared was incorporated to soil at the rate of $300 \mathrm{~g}$ formulation/ $\mathrm{m}$ length of the row. A cavity $15-\mathrm{cm}$ in depth was made in the surface of each row. Then the powder preparation of each treatment was added to this cavity and then recovered with the soil and immediately irrigated. One week after incorporation, surface disinfected garlic cloves (cv. Sides 40) were planted in each row. Garlic cloves that had been uniformly sized were hand planted 3 inches deep in rows spaced $10 \mathrm{~cm} \times 10 \mathrm{~cm}$ within each row. Based on garlic production regimes, the plots were planted with garlic cloves in 15-September of 2016 of 2016/2017 growing season and the experiment was repeated in $2017 / 2018$ growing season. The chemical treatment was applied by dipping garlic cloves before sowing in fungicide formulation (1.0 ml Folicur/L) for $5 \mathrm{~min}$. One month later, stem bases of garlic plants were sprayed (tow times) with the same concentration of Folicur at 6-weeks intervals. Irrigation and fertilization for garlic were conducted with commercial production in the area. White rot disease evaluations were conducted periodically during the growing season based on top symptoms of white rot, and were confirmed by gently removing some soil from around the base of some plants. At harvest, bulbs with symptoms of white rot were assessed by pulling and observing all garlic bulbs in each plot. The percentage of infected plants as well as white rot reduction (\%) was calculated according to Hovius and McDonald [18] as follows:

$$
\begin{gathered}
\text { White rot infection }(\%)=\frac{\text { No of infected plants with white rot }}{\text { Total no. of plants }} \times 100 \\
\text { White rot reduction }(\%)=\frac{\text { White } \operatorname{rot}(\%) \text { in control }- \text { White rot }(\%) \text { in treatment }}{\text { White rot }(\%) \text { in control }} \times 100
\end{gathered}
$$

\subsubsection{Effect of Sclerotial Mycoparasites on Enzymatic Activities in Garlic Plants}

The effect of Ch. globosum (Chg6), C. rosea (Cr12) and $P$. oxalicum (Po9) alone and their dual and triple combinations on the activities of the defense enzymes of peroxidase, polyphenoloxidase and chitinase of garlic plants was estimated at 100 days after planting. To extract the enzyme, garlic-leave samples $(\mathrm{g})$ were homogenized with $0.2 \mathrm{M}$ Tris $\mathrm{HCl}$ buffer $(\mathrm{pH} 7.8)$ at $0^{\circ} \mathrm{C}$ containing $14 \mathrm{~m} \mathrm{M} \mathrm{B-}$ mercaptoethanol at the rate of $1 / 3 \mathrm{w} / \mathrm{v}$. The extracts were obtained by filtering off the debris with a clean cloth and centrifuging at 3,000 rpm for $15 \mathrm{~min}$. The supernatants were recovered and kept in a tube in an ice bath until assayed. The supernatant was used to determine the activity of enzymes using UV spectrophotometer. Peroxidase activity was assayed with guaiacol as the hydrogen donor as described by Hammerschmidt et al. [19] and peroxidase activity was expressed as the increase in absorbance at $470 \mathrm{~nm} / \mathrm{g}$ fresh weight/ minute according to the method described by Lee [20]. Polyphenoloxidase enzyme activity was determined by measuring the rate of quinone formation as a result of oxidizing 3,4- dihydroxyphenylalanine (DOPA) and polyphenoloxidase activity was expressed as the increase in absorbance at $475 \mathrm{~nm} / \mathrm{g}$ fresh weight/minute according to the method described by Bashan et al. [21]. The determination of chitinase enzyme was carried out using colloidal chitin as substrate and dinitrosalicylic acid (DNS) as reagent to measure reducing sugars according the method described by Monreal and Reese [22]. Chitinase activity was expressed as $\mathrm{mM} \mathrm{N}$-acetylglucose amine equivalent released/ gram fresh weight/ 60 minutes at $450 \mathrm{~nm}$.

\subsubsection{Effect of Sclerotial Mycoparasites on Plant Growth and Bulb Yield}

The effect of Ch. globosum (Chg6), C. rosea (Cr12) and $P$. oxalicum (Po9) alone and their dual and triple combinations on plant growth were studied on onion and garlic grown under field conditions. The isolates alone and their dual and triple combinations and chemical fungicide were applied as described in field experiments. Four replicates were used per treatment. Negative control plots were treated with wheat bran free of antagonistic fungi. At 100 days after planting, some vegetative growth parameters: average plant height (cm), average number of leaves/plant and average plant biomass $(\mathrm{g})$, of each crop was estimated. At the end of the experiment (180 days for garlic after planting), fresh weight of onion and garlic plants (bulbs with the tops of the plants) within each plot were weighed. Efficacy of treatments was calculated using the following formula: Efficacy $(\%)=$ Fresh weight of plants in control- Fresh weight of plants in treatment/ Fresh weight of plants in control $\times 100$. 


\subsection{Statistical Analysis}

Data were entered into SPSS software version 14.0 and analyzed statistically by the analysis of variance test (ANOVA) and the means were compared by Duncan's multiple range test at $P<0.05$. Data collected from field experiments were analyzed separately for each growing season. Data for percentage germinated sclerotia and percent data on disease incidence were statistically analyzed after arcsine square-root transformation; however, untransformed data are presented.

\section{Results and Discussion}

\subsection{Laboratory Experiments}

\subsubsection{Antagonistic Activity}

The effects of the three sclerotial mycoparasites i.e, Ch. globosum (Chg6), C. rosea (Cr12) and P. oxalicum (Po9) on S. cepivora (Sc8) were investigated. Characteristics of the interaction between these isolates and S. cepivora $(\mathrm{Sc} 8)$ are given in Table 1. Chaetomium globosum isolate (Chg6) produced type B reaction inhibiting the growth of $S$. cepivora and growing over the colony. Clonostachys rosea $(\mathrm{Cr} 12)$ and Penicillium oxalicum (Po9) isolates displayed type D reaction producing zone of inhibition of 9.0 and $8.25 \mathrm{~cm}^{2}$, respectively. The inhibition in the growth and sclerotial formation of S. cepivora ( $\mathrm{Sc} 8$ ) caused by Ch. globosum (Chg6), C. rosea (Cr12) and P. oxalicum (Po9) were 59.1; $55.6,39.1 ; 56.5$ and $53.6 ; 57.1 \%$, respectively.

\subsubsection{Parasitism of Sclerotia}

The isolates of Ch. globosum (Chg6), C. rosea $(\mathrm{Cr} 12)$ and P. oxalicum (Po9) were seen to colonize the surface of sclerotia of $S$. cepivora (Sc8) (Table 1). The inner tissues of sclerotia appeared degraded and resulted in collapse of the outer rind. Parasitized sclerotia failed to germinate when they were transferred onto fresh PDA plates indicating that the sclerotia of $S$. cepivora ( $\mathrm{Sc} 8$ ) had been killed by these mycoparasites.

Table 1. Reaction type, growth area $\left(\mathrm{cm}^{2}\right)$, inhibition zone and number of sclerotia/ $\mathrm{cm}^{2}$ of garlic isolate Stromatinia cepivora (Sc8) in dual culture with sclerotial mycoparasites.

\begin{tabular}{llllll}
\hline Treatment & Reaction type $^{(\mathbf{a})}$ & Growth area $\left.\mathbf{( c m}^{\mathbf{2}}\right)^{(\mathbf{b})}$ & Inhibition zone $\left.\mathbf{( c m}^{2}\right)$ & No. of sclerotia in $\left(\mathbf{c m}^{2}\right)$ & Parasitism \\
\hline Ch. globosum (Chg6) & B & $26.00 \pm 0.41 \mathrm{~d}^{(\mathrm{d})}$ & $0.00 \pm 0.00 \mathrm{~b}$ & $35.5 \pm 0.87 \mathrm{~b}$ & + \\
C. rosea (Cr12) & D & $38.75 \pm 0.48 \mathrm{~b}$ & $9.00 \pm 0.58 \mathrm{a}$ & $34.8 \pm 0.48 \mathrm{~b}$ & + \\
P. oxalicum (Po9) & D & $29.50 \pm 0.29 \mathrm{c}$ & $8.25 \pm 0.25 \mathrm{a}$ & $34.3 \pm 0.25 \mathrm{~b}$ & + \\
Control & - & $63.6 \pm 0.00 \mathrm{a}$ & $0.00 \pm 0.00 \mathrm{~b}$ & $80.0 \pm 0.00 \mathrm{a}$ & - \\
\hline
\end{tabular}

Note: ${ }^{(a)}$ Reaction type produced in dual culture; B The growing margins of the two colonies meet, $S$. cepivora (Sc8) is inhibited and overgrown by the other fungus; D The growth of $S$. cepivora $(\mathrm{Sc} 8)$ is inhibited at a distance, leaving a clear zone of inhibition between the two organisms.

(b) Growth area $\left(\mathrm{cm}^{2}\right)$ of $S$. cepivora $(\mathrm{Sc} 8)$ was calculated using a planimeter.

(c) $(-)$ unparasitized, $(+)$ sclerotia parasitized.

${ }^{\text {(d) }}$ Means \pm standard deviations within a column followed by the same letter are not significantly different by Duncan multiple range test at $P<0.05$.

\subsubsection{Inhibitor Effect of Cultural Filtrate to S. cepivora (Sc8) Growth}

Culture filtrates of sclerotial mycoparasites had significant effects on the growth of S. cepivora (Sc8) (Table 2). $P$. oxalicum (Po9) was the most effective followed by $C h$. globosum (Chg6) and C. rosea (Cr12). Filtrates of these isolates were fungistatic. The filtrates caused substantial reduction in growth rate and also caused changes in growth form. Culture filtrates of $P$. oxalicum (Po9) was the most effective followed by Ch. globosum (Chg6), inhibiting the growth of $S$. cepivora $(\mathrm{Sc} 8)$ by $90.8 \& 85.0 \%$ and $87.2 \&$ $80.8 \%$, after 7 and 14 days of inoculation respectively. The chemical treatment with tebuconazole completely inhibited the growth of $S$. cepivora (Sc8) after both durations. The inhibited colonies of $S$. cepivora ( $\mathrm{Sc} 8)$ after 14 days were usually compact and dense, the hyphae were generally more branched and no sclerotia were formed. Obtained data are in agreement with those reported by Harrison and Stewart [23] and by Elshahawy et al. [11]. Ch.globosum, C. rosea (syn. Gliocladium roseum Bainier) and $P$. oxalicum have been shown to be biocontrol agent against several soil-borne plant pathogens [24, 25]. Tathan et al. [26] reported that Ch. globosum inhibited the spore production of Bipolaris oryzae (Breda de Haan) Shoemaker by $87.94 \%$. Characterization of antifungal metabolites of Ch. globosum was studied by Biswas et al. [27] and they reported that five metabolites produced by Ch. globosum of which two metabolites, viz. chaetoglobosin and chaetomin proved effective in suppressing the growth of Bipolaris sorokiniana Shoemaker, Gibberella zeae (Schwein.) Petch, Globisporangium ultimum (Trow) Uzuhashi, Macrophomina phaseolina (Tassi) Goid. And Thanatephorus cucumeris (A. B. Frank) Donkunder in vitro conditions.

Table 2. Growth of Stromatinia cepivora $(\mathrm{Sc} 8)$ in the presence of $10 \%$ cultural filtrates of sclerotial mycoparasites in vitro.

\begin{tabular}{llll}
\hline \multirow{2}{*}{ Treatment } & \multicolumn{2}{l}{ S. cepivora growth (mm) } & \\
\cline { 2 - 4 } & After 7 days & After 14 days & Change in growth form $^{(\text {a) }}$ \\
\hline Ch. globosum (Chg6) & $11.5 \pm 0.50 \mathrm{c}^{(\mathrm{b})}$ & $17.3 \pm 0.48 \mathrm{c}$ & + \\
C. rosea (Cr12) & $19.5 \pm 0.29 \mathrm{~b}$ & $23.5 \pm 0.29 \mathrm{~b}$ & + \\
P. oxalicum (Po9) & $08.3 \pm 0.25 \mathrm{~d}$ & $13.5 \pm 0.29 \mathrm{~d}$ & + \\
\hline
\end{tabular}




\begin{tabular}{llll}
\hline \multirow{2}{*}{ Treatment } & \multicolumn{2}{l}{ S. cepivora growth $(\mathbf{m m})$} & \multicolumn{2}{c}{ Change in growth form $^{(\mathbf{a})}$} \\
\cline { 2 - 4 } & After 7 days & After 14 days & ++ \\
\hline Tebuconazole $^{(\mathrm{c})}$ & $00.0 \pm 0.00 \mathrm{e}$ & $00.0 \pm 0.00 \mathrm{e}$ & - \\
Water (negative control) & $90.0 \pm 0.00 \mathrm{a}$ & $90.0 \pm 0.00 \mathrm{a}$ & + \\
\hline
\end{tabular}

Note: ${ }^{(a)}(-)$ no change $(+)$ colony compact and dense, hyphae more branched and no sclerotia formed and $(++)$ no growth.

${ }^{(b)}$ Means \pm standard deviations within a column followed by the same letter are not significantly different by Duncan multiple range test at $P<0.05$.

${ }^{(c)}$ The fungicide Tebuconazole was used as recommended dose of $1.0 \mathrm{ml}$ Folicur/liter.

\subsubsection{Inhibitor Effect of Cultural Filtrate to Sclerotial Germination}

The three sclerotial mycoparasites culture filtrates decreased S. cepivora (Sc8) sclerotial germination after soaking for $12 \mathrm{~h}$ (Table 3). P. oxalicum (Po9) filtrate caused the greatest reduction $(67.9 \%)$ in sclerotial germination, followed by Ch. globosum (Chg6) filtrate, which caused $55.2 \%$ reduction. C. rosea ( $\mathrm{Cr} 12)$ culture filtrate caused the least reduction $(47.3 \%)$. The chemical treatment with tebuconazole completely inhibited the sclerotial germination of $S$. cepivora (Sc8) after they were soaked for $12 \mathrm{~h}$. The present data are in accordance with those obtained by Elshahawy et al. [11], who reported that the percentage of germinated sclerotia of onion isolate of S. cepivora $(\mathrm{Sc} 2)$ soaking in filtrates of P. oxalicum (Po9), Ch. globosum (Chg6) and C. rosea (Cr12) were 28.9, 42.5 and 47.5\%, compared with $96.7 \%$ for the control. This suggests that filtrates of the sclerotial mycoparasites may contain lytic enzymes or antibiotics, as found by others. Ahammed et al. [28] purified and characterized an extracellular $\beta$-1, 3glucanase produced by Ch. globosum (Chg 2). Tweddell et al. [29] stated the role of cell wall degrading enzymes such as $\beta-1,3$ glucanases, chitinases, proteases, cellulases, xylanases, esterases, alkaline phosphatase and lipase by mycoparasites during interactions with other fungi. Pachenari and Dix [30] reported that C. rosea (syn. Gliocladium roseum Bainier) produces toxins and wall degrading enzymes affecting the germination of sclerotia.

Table 3. Sclerotial germination (\%) of S. cepivora (Sc8) after they were soaked in cultural filtrates ofsclerotial mycoparasites as well as chemical fungicide and water in vitro.

\begin{tabular}{lll}
\hline Treatment & Sclerotial germination (\%) & Reduction (\%) \\
\hline Ch. globosum (Chg6) & $43.3 \pm 0.48 \mathrm{c}^{\text {(a) }}$ & 55.2 \\
C. rosea $(\mathrm{Cr} 12)$ & $51.0 \pm 0.58 \mathrm{~b}$ & 47.3 \\
P. oxalicum (Po9) & $31.0 \pm 0.58 \mathrm{~d}$ & 67.9 \\
Tebuconazole ${ }^{\text {(c) }}$ & $00.0 \pm 0.00 \mathrm{e}$ & 100.0 \\
Water (negative control) & $96.7 \pm 1.36 \mathrm{a}$ & - \\
\hline
\end{tabular}

Note:Values are mean of four replications for each treatment as well as the control.

(b) Means \pm standard errors within a column followed by the same letter are not significantly different by Duncan multiple range test at $P<0.05$.

${ }^{\text {(c) }}$ The fungicide tebuconazole was used as recommended dose of $1.0 \mathrm{ml}$ Folicur/liter.

\subsection{Greenhouse Experiments}

The chemical treatment was the most effective, with the least percentage of white rot disease in garlic $(20.0 \%$ in $2016 / 2017$ season and $25.0 \%$ in $2017 / 2018$ season), in comparison with $100 \%$ for the control (Table 4). The sclerotial mycoparasites (either individually or in combination) significantly reduced the incidence of white rot on garlic. In general, dual and triple combinations of the sclerotial mycoparasites were more effective than these isolates used individually. The combination of all three sclerotial mycoparasites was the most effective treatment, decreasing disease incidence by 60.0 in 2016/2017 season and $55.0 \%$ in $2017 / 2018$ season. The obtained reduction in invaded garlic plants with $S$. cepivora (Sc8) may be attributed to the high accumulative inoculums potential of the introduced mycoparasites into the root region, before sowing and throughout the growing season as well, where they have a direct impact on sclerotia population. Similar explanation was reported by Kay and Stewart [31].

Table 4. Effects on white rot incidence (\%) in garlic due to application of selected sclerotial mycoparasites and their combinations under greenhouse conditions.

\begin{tabular}{|c|c|c|c|c|}
\hline \multirow{3}{*}{ Treatment } & \multicolumn{4}{|c|}{ White rot incidence (\%) and seveity } \\
\hline & \multicolumn{2}{|c|}{ 2016/2017 season } & \multicolumn{2}{|c|}{$2017 / 2018$ season } \\
\hline & Incidence (\%) & Reduction (\%) & Incidence (\%) & Reduction (\%) \\
\hline Ch. globosum (Chg6) & $60.0 \pm 0.00 \mathrm{c}^{(\mathrm{a})}$ & 40.0 & $65.0 \pm 5.00 \mathrm{~b}$ & 35.0 \\
\hline C. rosea (Cr12) & $75.0 \pm 5.00 \mathrm{~b}$ & 25.0 & $65.0 \pm 5.00 \mathrm{~b}$ & 35.0 \\
\hline P. oxalicum (Po9) & $60.0 \pm 0.00 \mathrm{c}$ & 40.0 & $65.0 \pm 5.00 \mathrm{~b}$ & 35.0 \\
\hline$($ Chg6) $+($ Cr12) & $60.0 \pm 0.00 \mathrm{c}$ & 40.0 & $55.0 \pm 5.00 \mathrm{bc}$ & 45.0 \\
\hline$(\mathrm{Cr} 12)+(\mathrm{Po} 9)$ & $55.0 \pm 5.00 \mathrm{~cd}$ & 45.0 & $50.0 \pm 5.77 \mathrm{bc}$ & 50.0 \\
\hline
\end{tabular}




\begin{tabular}{|c|c|c|c|c|}
\hline \multirow{3}{*}{ Treatment } & \multicolumn{4}{|c|}{ White rot incidence (\%) and seveity } \\
\hline & \multicolumn{2}{|c|}{$2016 / 2017$ season } & \multicolumn{2}{|c|}{$2017 / 2018$ season } \\
\hline & Incidence (\%) & Reduction (\%) & Incidence (\%) & Reduction (\%) \\
\hline$($ Chg6 $)+($ Cr12) $+($ Po9 $)$ & $40.0 \pm 0.00 \mathrm{e}$ & 60.0 & $45.0 \pm 5.00 \mathrm{c}$ & 55.0 \\
\hline Tebuconazole & $20.0 \pm 0.00 \mathrm{f}$ & 80.0 & $25.0 \pm 5.00 \mathrm{~d}$ & 75.0 \\
\hline Control & $100.0 \pm 0.00 \mathrm{a}$ & - & $100.0 \pm 0.00 \mathrm{a}$ & - \\
\hline
\end{tabular}

Note:Values are mean of five replicates for each treatment as well as the control.

${ }^{(b)}$ Means \pm standard errors within a column followed by the same letter are not significantly different by Duncan multiple range test at $P<0.05$.

\subsection{Field Experiments}

Results of the two trials followed the same trends, but the amount of white rot was related to inoculum density. The mean disease incidence and severity of $S$. cepivora infection among plants in soil containing 40 sclerotia/ $/ \mathrm{kg}$ of soil were significantly less than in those containing 600 sclerotia $/ \mathrm{kg}$ of soil. In general, the sclerotial mycoparasites were more effective in reducing garlic white rot disease in the trial with low inoculum density than in high inoculum density (Table 5). In the low inoculum density trial, the chemical treatment was the most effective, with the lowest disease incidence (7.75\% in 2016/2017 season and $13.0 \%$ in $2017 / 2018$ season), compared with $24.00 \%$ in $2016 / 2017$ season and $47.5 \%$ in 2017/2018 season for the controls (Table 5). In general, the dual and triple combinations of the tested sclerotial mycoparasites isolates were more effective than these isolates used individually. The combination of all three sclerotial mycoparasites was the most effective treatment, decreasing disease incidence by $70.8 \%$ in $2016 / 2017$ season and $73.7 \%$ in $2017 / 2018$ season. Such results are in agreement with the earlier findings of Kay and Stewart [31] and Elshahawy et al. [11]. These results also agree with those reported recently by many researchers $[25,32,33]$. They reported that Chaetomium globosum, $P$. oxalicum and $C$. rosea (syn. Gliocladium roseum Bainier) reducing damage caused by seed rot and damping off, of several seed- and soilborne plant pathogens. In New Zealand, under controlled conditions, Ch. globosum provided an average of about $73 \%$ suppression of onion white rot over two years [31]. They confirmed that the use of Ch. globosum is as effective as Trichoderma harzianum Rifai and Trichoderma viride Pers. Penicillium oxalicum reduced vascular wilts caused by Verticillium dahliae Kleb. and Fusarium oxysporum f. sp. lycopersici (Sacc.) Snyder \& H. N. Hansen under glasshouse and field conditions [25]. Hoitink and Boehm [34] have reported several types of mechanisms that are used by biocontrol agents. These include competition for nutrients and ecological niches, parasitism and production of cell-wall hydrolytic enzymes and/or of antifungal compounds.

Table 5. Effects on white rot disease incidence (\%) in garlic due to application of selected sclerotial mycoparasites and their combinations under field conditions.

\begin{tabular}{|c|c|c|c|c|}
\hline \multirow{2}{*}{ Treatment } & \multicolumn{4}{|c|}{ White rot incidence $(\%)$ and reduction $(\%)$} \\
\hline & Incidence (\%) & Reduction (\%) & Incidence (\%) & Reduction (\%) \\
\hline & \multicolumn{4}{|c|}{$2016 / 2017$ growing season } \\
\hline & \multicolumn{2}{|c|}{ Trial I (40 sclerotia/kg soil) } & \multicolumn{2}{|c|}{ Trial II (600 sclerotia/kg soil) } \\
\hline Ch. globosum (Chg6) & $16.00 \pm 0.71 \mathrm{c}^{(\mathrm{a})}$ & 33.3 & $80.25 \pm 0.25 \mathrm{a}$ & 0.9 \\
\hline C. rosea $(\mathrm{Cr} 12)$ & $19.50 \pm 0.50 \mathrm{~b}$ & 18.8 & $80.25 \pm 0.25 \mathrm{a}$ & 0.9 \\
\hline P. oxalicum (Po9) & $13.75 \pm 0.25 \mathrm{~d}$ & 42.7 & $80.00 \pm 0.00 \mathrm{a}$ & 1.2 \\
\hline$($ Chg6) $+($ Cr12) & $12.50 \pm 0.29 \mathrm{~d}$ & 47.9 & $62.75 \pm 0.25 \mathrm{c}$ & 22.5 \\
\hline$($ Chg6) $+($ Po9) & $9.50 \pm 0.29 \mathrm{e}$ & 60.4 & $64.25 \pm 0.48 b$ & 20.7 \\
\hline$(\mathrm{Cr} 12)+(\mathrm{Po} 9)$ & $9.25 \pm 0.25 \mathrm{e}$ & 61.5 & $63.75 \pm 0.25 \mathrm{~b}$ & 21.3 \\
\hline$($ Chg6) $+(\mathrm{Cr} 12)+(\mathrm{Po} 9)$ & $7.00 \pm 0.00 \mathrm{f}$ & 70.8 & $60.00 \pm 0.00 \mathrm{~d}$ & 25.9 \\
\hline Tebuconazole & $7.75 \pm 0.25 \mathrm{f}$ & 67.7 & $54.75 \pm 0.25 \mathrm{e}$ & 32.4 \\
\hline \multirow[t]{3}{*}{ Control } & $24.00 \pm 1.35 \mathrm{a}$ & - & $81.00 \pm 0.58 \mathrm{a}$ & - \\
\hline & \multicolumn{4}{|c|}{$2017 / 2018$ growing season } \\
\hline & \multicolumn{2}{|c|}{ Trial I (40 sclerotia/kg soil) } & \multicolumn{2}{|c|}{ Trial II (600 sclerotia/kg soil) } \\
\hline Ch. globosum (Chg6) & $21.75 \pm 0.25 \mathrm{bc}$ & 54.2 & $83.50 \pm 0.29 \mathrm{ab}$ & 2.9 \\
\hline C. rosea $(\mathrm{Cr} 12)$ & $23.00 \pm 0.71 \mathrm{~b}$ & 51.6 & $84.00 \pm 0.71 \mathrm{ab}$ & 2.3 \\
\hline P. oxalicum (Po9) & $21.00 \pm 0.41 \mathrm{c}$ & 55.8 & $83.00 \pm 0.41 \mathrm{~b}$ & 3.5 \\
\hline$($ Chg6) $+($ Cr12) & $15.50 \pm 0.29 \mathrm{~d}$ & 67.4 & $71.00 \pm 0.41 \mathrm{c}$ & 17.4 \\
\hline$($ Chg6) $+($ Po9) & $16.25 \pm 0.48 \mathrm{~d}$ & 65.8 & $69.00 \pm 0.71 \mathrm{c}$ & 19.8 \\
\hline$(\mathrm{Cr} 12)+(\mathrm{Po} 9)$ & $16.25 \pm 0.48 \mathrm{~d}$ & 65.8 & $69.25 \pm 0.63 \mathrm{c}$ & 19.5 \\
\hline$($ Chg6) $+(\mathrm{Cr} 12)+(\mathrm{Po} 9)$ & $12.50 \pm 0.65 \mathrm{e}$ & 73.7 & $62.25 \pm 1.93 \mathrm{~d}$ & 27.6 \\
\hline Tebuconazole & $13.00 \pm 0.58 \mathrm{e}$ & 72.6 & $59.25 \pm 0.48 \mathrm{e}$ & 31.1 \\
\hline Control & $47.50 \pm 1.19 \mathrm{a}$ & - & $86.00 \pm 0.71 \mathrm{a}$ & - \\
\hline
\end{tabular}

Note:Values are mean of four replications for each bacterium as well as the control.

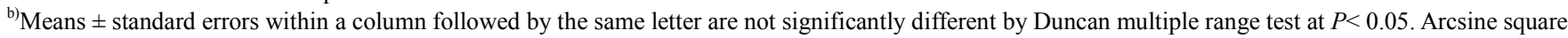
root-transformed data for disease incidence (\%) were conducted for statistic analysis; however, untransformed data are presented. 


\subsubsection{Effects on Enzymatic Activities in Garlic Plants}

Results of the two trails followed the same trends. The tested sclerotial mycoparasites used either individually or in combination were pronounced in induction of defense enzyme in comparison with the control. In general, the dual and triple combinations were more effective than used these isolates individually (Table 6). The triple combination of all sclerotial mycoparasites was the most effective treatment, induced high activation of peroxidase, polyphenoloxidase and chitinase by $70.3 ; 67.3,59.9 ; 61.0$ and $56.6 ; 60.6 \%$ increase over control, under low and high inoculum density, respectively. A positive correlation between the biocontrol activates of sclerotial mycoparasites isolates and enhancement of peroxidase, polyphenoloxidase and chitinase enzymes in garlic to resist infection with $S$. cepivora. The reduction in garlic white rot disease incidencemay is due to an increase in the defense-related enzymes such as peroxidase, polyphenoloxidase and chitinase. These results also are in agreement with those obtained by De Cal et al. [35]. They reported that induction of resistance in tomato plants was demonstrated as the main mode of action of $P$. oxalicum against Fusarium oxysporum f. sp. lycopersici. They added that this resistance was also observed both in sensitive and resistant cultivars indicating the role of general resistance mechanism. Recently, Aggarwal [36] investigated the important parameters of induced resistance in wheat (Triticum aestivum) against B. sorokiniana and Puccinia recondita Roberge ex Desm. using biocontrol agent $C$. globosum. Enhanced activities of defense related enzymes polyphenoloxidase, peroxidase, phenylalanine lyase and catalase revealed the role in induction of systemic resistance. The results indicate that the biocontrol agent induced effective defense responses in wheat plants against $B$. sorokiniana and $P$. triticina. The reduced disease incidence in wheat by Ch. globusum may be a result of cell wall strengthening through deposition of lignin and induction of defense enzymes. The oxidative enzymes play an important role in induced resistance by the oxidation of phenols to oxidized toxic products (quinine) which limit fungal activity. Peroxidases catalyze a number of reactions that fortify plant cell walls. These reactions include the incorporation of phenolics into cell walls and lignifications and suberization of plant cell walls. On the other hand, the chitinase enzymes play roles in plant defense against fungi by hydrolyze their cell wall. The amount of them significantly increase and play main role of defense reaction against fungal pathogen by degrading cell wall, because chitin is a major structural component of the cell walls of many pathogenic fungi $[19$, $37,38,39]$.

Table 6. Effects on peroxidase, polyphenoloxidase and chitinase enzymes activities of garlic plants from application of selected sclerotial mycoparasitesand their combinations under field conditions at 100 days after planting.

\begin{tabular}{|c|c|c|c|}
\hline \multirow{2}{*}{ Treatment } & \multicolumn{3}{|c|}{ Enzyme activities in garlic leaves ${ }^{(a)}$} \\
\hline & Peroxidase & Polyphenoloxidase & Chitinase \\
\hline & \multicolumn{3}{|l|}{ Trial I (40 sclerotia/kg soil) } \\
\hline Ch. globosum (Chg6) & $0.307 \pm 0.008 \mathrm{bcd}$ & $0.389 \pm 0.019 \mathrm{e}$ & $1.359 \pm 0.066 \mathrm{~d}$ \\
\hline C. rosea $(\mathrm{Cr} 12)$ & $0.296 \pm 0.011 \mathrm{~d}$ & $0.389 \pm 0.017 \mathrm{e}$ & $1.314 \pm 0.075 \mathrm{~d}$ \\
\hline P. oxalicum (Po9) & $0.298 \pm 0.006 \mathrm{~cd}$ & $0.395 \pm 0.012 \mathrm{e}$ & $1.405 \pm 0.029 \mathrm{~cd}$ \\
\hline$($ Chg6) $+($ Cr12) & $0.318 \pm 0.006 \mathrm{bcd}$ & $0.509 \pm 0.009 \mathrm{c}$ & $1.495 \pm 0.014 \mathrm{bc}$ \\
\hline$($ Chg6) $+($ Po9) & $0.330 \pm 0.003 \mathrm{bc}$ & $0.521 \pm 0.005 \mathrm{bc}$ & $1.572 \pm 0.005 \mathrm{~b}$ \\
\hline$(\mathrm{Cr} 12)+(\operatorname{Po} 9)$ & $0.335 \pm 0.002 \mathrm{~b}$ & $0.545 \pm 0.005 \mathrm{ab}$ & $1.571 \pm 0.008 \mathrm{~b}$ \\
\hline$($ Chg6) $+(\mathrm{Cr} 12)+(\operatorname{Po} 9)$ & $0.397 \pm 0.020 \mathrm{a}$ & $0.563 \pm 0.007 \mathrm{a}$ & $1.757 \pm 0.035 \mathrm{a}$ \\
\hline Tebuconazole & $0.295 \pm 0.019 \mathrm{~d}$ & $0.454 \pm 0.014 \mathrm{~d}$ & $1.386 \pm 0.052 \mathrm{~cd}$ \\
\hline \multirow[t]{2}{*}{ Control } & $0.118 \pm 0.002 \mathrm{e}$ & $0.226 \pm 0.004 \mathrm{f}$ & $0.763 \pm 0.022 \mathrm{e}$ \\
\hline & \multicolumn{3}{|l|}{ Trial II (600 sclerotia/kg soil) } \\
\hline Ch. globosum (Chg6) & $0.332 \pm 0.009 \mathrm{c}$ & $0.453 \pm 0.028 \mathrm{c}$ & $1.539 \pm 0.054 \mathrm{c}$ \\
\hline C. rosea $(\mathrm{Cr} 12)$ & $0.294 \pm 0.003 \mathrm{~d}$ & $0.431 \pm 0.019 \mathrm{c}$ & $1.421 \pm 0.014 \mathrm{c}$ \\
\hline P. oxalicum (Po9) & $0.324 \pm 0.008 \mathrm{c}$ & $0.466 \pm 0.026 \mathrm{c}$ & $1.522 \pm 0.014 \mathrm{c}$ \\
\hline$($ Chg6) $+($ Cr12) & $0.379 \pm 0.020 \mathrm{~b}$ & $0.574 \pm 0.024 \mathrm{~b}$ & $1.809 \pm 0.034 \mathrm{~b}$ \\
\hline$($ Chg6) $+($ Po9) & $0.391 \pm 0.015 \mathrm{~b}$ & $0.607 \pm 0.009 \mathrm{ab}$ & $1.776 \pm 0.019 \mathrm{~b}$ \\
\hline$(\mathrm{Cr} 12)+(\operatorname{Po} 9)$ & $0.399 \pm 0.012 \mathrm{ab}$ & $0.605 \pm 0.008 \mathrm{ab}$ & $1.721 \pm 0.047 \mathrm{~b}$ \\
\hline$($ Chg6) $+(\mathrm{Cr} 12)+(\mathrm{Po} 9)$ & $0.425 \pm 0.025 \mathrm{a}$ & $0.613 \pm 0.015 \mathrm{a}$ & $1.994 \pm 0.067 \mathrm{a}$ \\
\hline Tebuconazole & $0.329 \pm 0.003 \mathrm{c}$ & $0.436 \pm 0.003 \mathrm{c}$ & $1.457 \pm 0.064 \mathrm{c}$ \\
\hline Control & $0.139 \pm 0.004 \mathrm{e}$ & $0.239 \pm 0.005 \mathrm{~d}$ & $0.786 \pm 0.017 \mathrm{~d}$ \\
\hline
\end{tabular}

Note: Values are mean of eight replicates for each treatment as well as the control.

(a) Peroxidase activity was expressed as the increase in absorbance at $470 \mathrm{~nm} / \mathrm{g}$ fresh weight/ minute. Polyphenoloxidase activity was expressed as the increase in absorbance at $475 \mathrm{~nm} / \mathrm{g}$ fresh weight/ minute. Chitinase activity was expressed as $\mathrm{mM} \mathrm{N}$-acetyl glucose amine equivalent released/ gram fresh weight/ 60 minutes at $540 \mathrm{~nm}$. Values are means of four replicates.

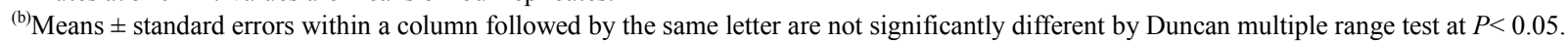

\subsubsection{Effects on Plant Growth and Bulb Yield in the Field}

The sclerotial mycoparasites and their combinations affected plant growth of garlic cv. Sides 40 in two field trials (Table 7). Results of the two trials followed the same trends but the amount of growth improvements was related to inoculum density. The mean growth parameters among plants in soil containing $40 \mathrm{sclerotia} / \mathrm{kg}$ were significantly greater than in soil containing 600 sclerotia/ $\mathrm{kg}$ of soil. In general, the sclerotial mycoparasites were more effective in improving 
garlic growth in the trial with low inoculum density compared with the trial with high inoculum density. In the low inoculums density trial, the triple combinations of the tested sclerotial mycoparasites isolates was the most effective, increasing average plant height by $23.9 \%$, increasing average number of leaves/plant by $31.5 \%$, increasing average plant biomass by $40.1 \%$, respectively (Table 7). The effects of soil application with sclerotial mycoparasites and their combinations on garlic bulb yield at two sites followed the same trend but the bulb yield was greater in soil with low inoculum density than with high inoculum density (Table 8). In general, the dual and triple sclerotial mycoparasites combinations were more effective than these isolates used individually (Table 8). P. oxalicum (Po9), Ch. globosum (Chg6) and C. rosea (Cr12) are well known from previous studies as plant growth-promoting agents. The ability of Penicillium oxalicum to improve the seed germination and seedling growth of cabbage has already been confirmed by Teshima and Sakamoto [40]. Fungal biocontrol agents enhanced the plant growth parameters by plant growth-promoting (PGPF) effects. Clonostachys rosea (syn. Gliocladium roseum Bainier), Penicillium oxalicum and Ch. globosum influence plant growth through numerous mechanisms, which mainly include enhancing the solubilization of soil nutrients [41,36], increasing root length and number of root hairs to explore larger spaces of soil to absorb nutrients [42] and improving the production of plant stimulatory compounds, such as growth hormones, i.e. indole acetic acid, cytokinin, gibberellins, and zeatin [43-46].

Table 7. Effects on average plant height, average number of leaves/plant and average plant biomass of garlic plants from application of selected sclerotial mycoparasites and their combinations under field conditions at 100 days after planting.

\begin{tabular}{|c|c|c|c|}
\hline \multirow{2}{*}{ Treatment } & \multicolumn{3}{|l|}{ Garlic plants grown in field ${ }^{(a)}$} \\
\hline & Plant height (cm) & Number of leaves/plant & Plant biomass (g) \\
\hline & \multicolumn{3}{|l|}{ Trial I (40 sclerotia/kg soil) } \\
\hline Ch. globosum (Chg6) & $68.15 \pm 2.56 \mathrm{bc}$ & $7.50 \pm 0.19 \mathrm{~cd}$ & $62.28 \pm 3.61 \mathrm{bc}$ \\
\hline C. rosea $(\mathrm{Cr} 12)$ & $65.55 \pm 2.88 \mathrm{~cd}$ & $7.13 \pm 0.29 \mathrm{~d}$ & $60.30 \pm 4.09 \mathrm{bc}$ \\
\hline P. oxalicum (Po9) & $67.41 \pm 2.36 \mathrm{bc}$ & $7.50 \pm 0.19 \mathrm{~cd}$ & $60.88 \pm 3.93$ \\
\hline$($ Chg6 $)+(\mathrm{Cr} 12)$ & $72.83 \pm 4.48 \mathrm{ab}$ & $7.88 \pm 0.13 \mathrm{bc}$ & $69.30 \pm 4.99 \mathrm{~b}$ \\
\hline$($ Chg6) $+($ Po9) & $73.05 \pm 4.38 \mathrm{ab}$ & $8.00 \pm 0.19 \mathrm{bc}$ & $68.88 \pm 5.19 \mathrm{~b}$ \\
\hline$($ Chg6) $+($ Cr12) $+($ Po9) & $76.00 \pm 4.45 \mathrm{a}$ & $9.13 \pm 0.23 \mathrm{a}$ & $82.63 \pm 9.89 \mathrm{a}$ \\
\hline Tebuconazole & $61.41 \pm 0.24 \mathrm{de}$ & $7.25 \pm 0.16 \mathrm{~d}$ & $54.30 \pm 0.64 \mathrm{~cd}$ \\
\hline Control & $57.80 \pm 0.71 \mathrm{e}$ & $6.25 \pm 0.25 \mathrm{e}$ & $49.53 \pm 1.06 \mathrm{~d}$ \\
\hline & \multicolumn{3}{|l|}{ Trial II (600 sclerotia/kg soil) } \\
\hline Ch. globosum (Chg6) & $54.61 \pm 2.31 \mathrm{c}$ & $7.00 \pm 0.00 \mathrm{c}$ & $42.66 \pm 2.65 \mathrm{~cd}$ \\
\hline C. rosea $(\mathrm{Cr} 12)$ & $54.60 \pm 2.29 \mathrm{c}$ & $7.13 \pm 0.13 \mathrm{bc}$ & $42.68 \pm 2.75 \mathrm{~cd}$ \\
\hline P. oxalicum (Po9) & $54.80 \pm 2.37 \mathrm{c}$ & $7.13 \pm 0.13 b c$ & $42.61 \pm 2.79 \mathrm{~cd}$ \\
\hline$(\mathrm{Cr} 12)+(\mathrm{Po} 9)$ & $57.51 \pm 2.65 b$ & $7.38 \pm 0.18 \mathrm{abc}$ & $46.25 \pm 2.91 \mathrm{~b}$ \\
\hline (Chg6) $+($ Cr12) $+($ Po9) & $61.98 \pm 2.89 \mathrm{a}$ & $7.63 \pm 0.18 \mathrm{a}$ & $51.65 \pm 3.58 \mathrm{a}$ \\
\hline Tebuconazole & $45.59 \pm 0.76 \mathrm{~d}$ & $6.00 \pm 0.18 \mathrm{~d}$ & $41.78 \pm 0.66 \mathrm{~d}$ \\
\hline Control & $39.56 \pm 0.76 \mathrm{e}$ & $5.50 \pm 0.19 \mathrm{e}$ & $32.40 \pm 0.72 \mathrm{e}$ \\
\hline
\end{tabular}

Note: ${ }^{(a)}$ Values are mean of eight replicates for each treatment as well as the control.

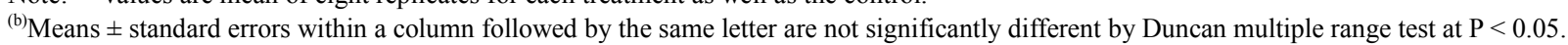

Table 8. Effect of selected sclerotial mycoparasites and their combinations on garlic bulb yield under field conditions.

\begin{tabular}{|c|c|c|c|c|}
\hline \multirow{2}{*}{ Treatment } & \multicolumn{4}{|c|}{ Garlic bulb yield (kg/plot) and efficiency of treatment $(\%)$} \\
\hline & Yield (kg/plot) & Efficiency (\%) & Yield (kg/plot) & Efficiency (\%) \\
\hline & \multicolumn{4}{|c|}{$2016 / 2017$ growing season } \\
\hline & \multicolumn{2}{|c|}{ Trial I (40 sclerotia/kg soil) } & \multicolumn{2}{|c|}{ Trial II (600 sclerotia/kg soil) } \\
\hline Ch. globosum (Chg6) & $21.8 \pm 0.27 \mathrm{c}$ & 26.6 & $9.8 \pm 0.03 \mathrm{~b}$ & 4.1 \\
\hline C. rosea $(\mathrm{Cr} 12)$ & $21.7 \pm 0.00 \mathrm{c}$ & 26.3 & $9.8 \pm 0.03 \mathrm{~b}$ & 4.1 \\
\hline P. oxalicum (Po9) & $21.7 \pm 0.03 \mathrm{c}$ & 26.3 & $9.8 \pm 0.03 \mathrm{~b}$ & 4.1 \\
\hline$($ Chg6) $+($ Cr12) & $23.5 \pm 0.04 \mathrm{~b}$ & 31.9 & $10.8 \pm 0.05 \mathrm{a}$ & 12.9 \\
\hline$(\mathrm{Cr} 12)+(\operatorname{Po} 9)$ & $23.6 \pm 0.03 \mathrm{~b}$ & 32.2 & $10.9 \pm 0.05 \mathrm{a}$ & 13.8 \\
\hline$($ Chg6) $+(\mathrm{Cr} 12)+(\mathrm{Po} 9)$ & $24.8 \pm 0.03 \mathrm{a}$ & 35.5 & $10.9 \pm 0.00 \mathrm{a}$ & 13.8 \\
\hline Tebuconazole & $18.2 \pm 0.20 \mathrm{~d}$ & 12.1 & $9.8 \pm 0.12 b$ & 4.1 \\
\hline Control & $16.0 \pm 0.17 \mathrm{e}$ & - & $9.4 \pm 0.15 \mathrm{c}$ & - \\
\hline \multicolumn{5}{|c|}{$2017 / 2018$ growing season } \\
\hline & \multicolumn{2}{|c|}{ Trial I (40 sclerotia/kg soil) } & \multicolumn{2}{|c|}{ Trial II (600 sclerotia/kg soil) } \\
\hline Ch. globosum (Chg6) & $20.5 \pm 0.05 \mathrm{c}$ & 32.2 & $8.4 \pm 0.14 \mathrm{c}$ & 5.9 \\
\hline P. oxalicum (Po9) & $20.6 \pm 0.08 \mathrm{c}$ & 32.5 & $8.3 \pm 0.13 \mathrm{~cd}$ & 4.8 \\
\hline$($ Chg6 $)+(\operatorname{Cr} 12)$ & $21.6 \pm 0.06 \mathrm{~b}$ & 35.6 & $9.2 \pm 0.11 \mathrm{~b}$ & 14.1 \\
\hline
\end{tabular}




\begin{tabular}{|c|c|c|c|c|}
\hline \multirow{2}{*}{ Treatment } & \multicolumn{4}{|c|}{ Garlic bulb yield (kg/plot) and efficiency of treatment (\%) } \\
\hline & Yield (kg/plot) & Efficiency (\%) & Yield (kg/plot) & Efficiency (\%) \\
\hline$($ Chg6) $+($ Po9) & $21.3 \pm 0.07 \mathrm{~b}$ & 34.7 & $9.4 \pm 0.08 \mathrm{ab}$ & 15.9 \\
\hline$(\mathrm{Cr} 12)+($ Po9) & $21.6 \pm 0.08 \mathrm{~b}$ & 35.6 & $9.6 \pm 0.12 \mathrm{ab}$ & 17.7 \\
\hline$($ Chg6) $)+(\mathrm{Cr} 12)+($ Po9) & $22.3 \pm 0.06 \mathrm{a}$ & 37.7 & $9.8 \pm 0.05 \mathrm{a}$ & 19.4 \\
\hline Tebuconazole & $16.0 \pm 0.18 \mathrm{~d}$ & 13.1 & $8.2 \pm 0.12 \mathrm{~cd}$ & 3.7 \\
\hline Control & $13.9 \pm 0.24 \mathrm{e}$ & - & $7.9 \pm 0.36 \mathrm{~d}$ & - \\
\hline
\end{tabular}

Note: Values are mean of four replicates for each treatment as well as the control.

${ }^{(a)}$ Means \pm standard errors within a column followed by the same letter are not significantly different by Duncan multiple range test at $P<0.05$.

\section{Conclusion}

The obtained results suggest that the potential for reducing white rot in garlic by soil application with inoculants containing sclerotial mycoparasites i.e., Chaetomium globosum (Chg6), Clonostachys rosea (Cr12) and Penicillium oxalicum (Po9) is absolutely influenced by the level of $S$. cepivora inocula. Under low inoculums levels (40 sclerotia/kg of soil) these sclerotial mycoparasites either alone or in combination may be useful for disease management. However, under high inoculums levels (600 sclerotia/kg of soil) triple combinations only give significant control of white rot. Reduction of white rot disease was accompanied by increasing growth parameters and bulb yield of garlic plants grown under field conditions.

\section{References}

[1] Palmero, D. L., Galvez, L. P., Garcia, M. D., Gil, J. S., and Benito, S. S. (2013) The effects of storage duration, temperature and cultivar on the severity of garlic clove rot caused by Fusarium proliferatum. Postharvest Biology and Technology, 78, 34-39.

[2] Anonymous (2017) Bulletin of the Agricultural Statistics. Ministry of Agric and Land Reclamation, pp 159.

[3] Elshahawy, I. E., Saied, N. M., and Morsy, A. A. (2017a) Fusarium proliferatum, the main cause of clove rot during storage, reduces clove germination and causes wilt of established garlic plants. Journal of Plant Pathology,99(1), 8189.

[4] Ulacio-Osorio, D., Zavaleta-Mejía, E., Martínez-Garza, A., and Pedroza-Sandoval A. (2006) Strategies for management of Sclerotium cepivorum Berk. in garlic. Journal of Plant Pathology, 88 (3), 253-261.

[5] Elshahawy, I. E., Saied, N., Abd-El-Kareem, F., and Morsy, A. (2018) Field application of selected bacterial strains and their combinations for controlling onion and garlic white rot disease caused by Stromatinia cepivora. Journal of Plant Pathology, (Accepted).

[6] Sammour, H. R., Mahmoud, A. G. Y., Mustafa, A. A., and Alhoziem, R. (2011) Biology, controlling and genetic viability in Scleratrium cepivorum Berk; the causal agent of Allium white rot. Current Trends in Microbiology,7,101-111.

[7] Crowe, F. J., Hall, D. H., Greathead, A. S., and Baghott, K. G. (1980) Inoculum density of Sclerotium cepivorum and the incidence of white rot of onion and garlic. Phytopathology, 70, 64-69.
[8] Dennis, J. J. (2001) Progress toward an integrated control strategy for onion white rot disease, including the use of artificial germination stimulants. Acta Horticulture, 555, 117-120.

[9] Fullerton, R. A., Stewart, A., and Slade, E. A. (1995) Use of demethylation inhibiting fungicides (DMIs) for the control of onion white rot (Sclerotium cepivorum Berk.) in New Zealand. New Zealand Journal of Crop and Horticultural Science, 23, 121-125.

[10] Earnshaw, D. M., McDonald, M. R., and Boland, G. J. (2000) Interactions among isolates and mycelial compatibility groups of Sclerotium cepivorum and cultivars of onion (Allium cepa). Canadian Journal of Plant Pathology,22, 387-391.

[11] Elshahawy, I. E., Saied, N., Abd-El-Kareem, F., and Morsy, A. (2017b) Field application of sclerotial mycoparasites as biocontrol agents to Stromatinia cepivora, the cause of onion white rot. Journal of Plant Pathology, 99 (2), 391-401.

[12] Bell, D. K., Wells, H. D., and Markham, C. R. (1982) In vitro antagonism of Trichoderma species against six fungal plant pathogens. Phytopathology, 72, 382-379.

[13] Mahdizadehnaraghi, R., Heydari, A., Zamanizadeh, H. R., Rezaee, S., and Nikan, J. (2015) Biological control of garlic (Allium) white rot disease using antagonistic fungi-based bioformulations. Journal of Plant Protection Research, 55(2), 136-141.

[14] Elsherbiny, A. E., Saad, A. S., Zaghloul, Mona G., and ElSheshtawi, M. A (2015) Efficiency assessment of the antifungal metabolites from Sclerotium cepivorum against onion white rot disease. European Journal of Plant Pathology, $142,843-854$

[15] El-Sheshtawi, M., El-Gazzar, T., and Saad, A. S. (2009) Comparative study between chemical and non-chemical control against Sclerotium cepivorum, the causal white rot of onion under Egyptian condition. Journal of Agricultural Science Mansoura University,34, 2169-2182.

[16] Zewide, T., Fininsa, C., and Sakhuja, P. K. (2007) Management of white rot (Sclerotium cepivorum) of garlic using fungicides in Ethiopia. Crop Protection, 26, 856-866.

[17] Utkhede, R. S., and Rahe, J. E. (1979). Wet sieving flotation technique for isolation of sclerotia of Sclerotium cepivorum from Muck soil. Phytopathology,69, 295-297.

[18] Hovius, M. H. Y., and Goldman, I. L. (2004) Evaluation of long-day onions for resistance to white rot infection using greenhouse and laboratory techniques. J. Amer. Soc. Horti. Sci., 129(2), 258-265.

[19] Hammerschmidt, R., Lamport, D. T. A., and Muldoon, E. P.(1984) Cell wall hydroxyproline enhancement and lignin deposition as an early event in the resistance of cucumber to Cladosporium cucumerinum. Physiological Plant Pathology, 24, 43-47. 
[20] Lee, N. T. (1973). On extraction and quantitation of plant peroxidase enzymes. Physiologia Plantarum,29, 198-203.

[21] Bashan, Y., Okon, Y., and Henis, Y. (1985) Peroxidase, polyphenol oxidase, and phenols in relation to resistance against 214 Pseudomonas syringae pv. tomato in tomato plants. Canadian Journal of Botany,65, 366-372.

[22] Monreal, J., and Reese, E. T. (1969) The chitinase of Serratia marcescens. Canadian Journal of Microbiology, 15, 689-696.

[23] Harrison, Y. A., and Stewart, A. (1988) Selection of fungal antagonists for biological control of onion white rot in New Zealand. New Zealand Journal of Experimental Agriculture, 16(3), 249-256.

[24] Soytong, K., Jindawong, N., Yang, Q. (1999) Evaluation of Chaetomium for biological control of Fusarium wilt of tomato in P. R. China. Proceedings of the 5 International Conference on Plant Protection in the Tropics, 15-18 March 1999, Malaysia, pp 484-487.

[25] Larena, I., Sabuquillo, P., Melgarejo, P., and De Cal, A. (2003) Biocontrol of Fusarium and Verticillium wilt of tomato by Penicillium oxalicum under greenhouse and field conditions. Journal of Phytopathology,151, 507-512.

[26] Tathan, S., Sibounnavong, P., Sibounnavong, P. S., Soytong, K., and To-anun, C. (2012) Biological metabolites from Chaetomium spp to inhibit Drechslera oryzae causing leaf spot of rice. Journal of Agricultural Technology,8(5), 16911701.

[27] Biswas, S. K., Aggarwal, R., Srivastava, K. D., Gupta, S., and Dureja, P. (2012) Characterization of antifungal metabolites of Chaetomium globosum Kunze and their antagonism against fungal plant pathogens. Journal of Biological Control, 26(1), 70-74.

[28] Ahammed, S. K., Aggarwal, R., Sharma, S., Gupta, S., and Bashyal, B. M. (2012)Production, partial purification and characterization of extra-cellular $\beta$-1, 3- glucanase from Chaetomium globosum and its antifungal activity against Bipolaris sorokiniana causing spot blotch of wheat. Journal of Mycology and Plant Pathology, 42, 146-152.

[29] Tweddell, J. R., Jabaji-Hare, S. H., and Charest, P. M. (1994) Production of chitinase and $\beta$-1, 3- glucanases by Stachybotrys elegans, a Mycoparasite of Rhizoctonia solani. Applied and Environmental Microbiology, 60, 489-495.

[30] Pachenari, A., and Dix, N. J. (1980) Production of toxins and wall degrading enzymes by Gliocladium roseum. Transactions of the British Mycological Society,74, 561-566.

[31] Kay, S. J., and Stewart, A. (1994) Evaluation of fungal antagonists for control of onion white rot in soil box trials. Plant Pathology,43, 371-377.

[32] Aggarwal, R., Tiwari, A. K., Srivastava, K. D., and Singh, D. V.(2004) Role of antibiosis in the biological control of spot blotch (Cochliobolus sativus) of wheat by Chaetomium globosum. Mycopathologia,157(4), 369-377.

[33] Hung, P. M., Pongnak, W., Soytong, K., and Supatta, P. (2015) Biological control of Phytophthora palmivora causing root rot of pomelo using Chaetomium spp. Mycobiology, 43(1), 63-70.
[34] Hoitink, H. A. J., and Boehm, M. J. (1999) Biocontrol within the context of soil microbial communities: a substratedependent phenomenon. Annual Review of Phytopathology, 37, 427-446.

[35] De Cal, A., Pascaual, S., and Melgarejo, P. (1997) Involvement of resistance induction by Penicillium oxalicum in the biological control of tomato wilt. Plant Pathology, 46, 72-79.

[36] Aggarwal, R. (2015)Chaetomium globosum: A potential biocontrol agent and its mechanism of action. Indian Phytopathology, 68 (1), 8-24.

[37] Kavroulakis, N., Ehaliotis, C., Ntougias, S., Zervakis, G. I., and Papadopoulou, K. K. (2005) Local and systemic resistance against fungal pathogens of tomato plants elicited by a compost from agricultural residues. Physiological and Molecular Plant Pathology, 66, 163-174.

[38] Chen, F., Min, W., Zheng, Y., Jianmei, L., Yang, X., and Wang, X. (2010) Quantitative changes of plant defense enzymes and phytohormone in biocontrol of cucumber Fusarium wilt by Bacillus subtilis B579. World Journal of Microbiology and Biotechnology, 26, 675-684.

[39] Jian, L., Rong-xiang, T., Zhong-na, H., Lian-ping, W., Xin, Z. (2011) Induction of resistance in cucumber against seedling damping-off by plant growth-promoting rhizobacteria (PGPR) Bacillus megaterium strain L8. African Journal of Biotechnology, 10, 6920-6927.

[40] Teshima, S., and Sakamoto, K. (2006) Promotion of the seed germination and seedling growth of cabbage by rootcolonizing fungi isolated from oats and eucalyptus roots. Japanese Journal of Soil Science and Plant Nutrition, 77, 265272.

[41] Moody, A. R., and Gindrat, D. (1977) Biological control of cucumber black root rot by Gliocladium roseum. Phytopathology, 67, 1159-1162.

[42] De Cal, A., Garcia-Lepe, R., and Melgarejo, P. (2000) Induced resistance by Penicillium oxalicum against Fusarium oxysporum f. sp. lycopersici: Histological studies of infected and induced tomato stems. Phytopathology, 90, 260-268.

[43] Hyakumachi, M. (1994) Plant growth promoting fungi from turf grass rhizosphere with potential of disease suppression. Soil Microorganisms, 4, 53-68.

[44] Zhai, X., Luo, D., Li, X., Han, T., Jia, M., Kong, Z., Ji, J., Rahman, K., Qin, L., and Zheng, C. (2018) Endophyte Chaetomium globosum d38 promotes bioactive constituents accumulation and root production in Salvia miltiorrhiza. Frontiers in Microbiology, 8, 2694, 1-13.

[45] Murali, M., and Amruthesh, K. N. (2015) Plant growthpromoting fungus Penicillium oxalicum enhances plant growth and induces resistance in pearl millet against downy mildew disease. Journal of Phytopathology, 163, 743-754.

[46] Mraga-Suazo, P., and Sanfuentes, E. (2017) Growth promotion of Pinus radiate seedlings by soil inoculation and seed pretreatment with the biological controla gent Clonostachys rosea. Gayana Botanica, 74(1), 82-88. 